\title{
Prevalence of Selected Non-Metric Dental Traits in Indo-Nepalese and Tibeto-Nepalese Ethnic Groups of Western Hilly Region
}

\author{
Sanjay Kumar Sah, ${ }^{1}$ Santosh Kandel, ${ }^{2}$ Raju Shrestha, ${ }^{2}$ Alok Atreya ${ }^{1}$ \\ 'Department of Forensic Medicine and Toxicology, Lumbini Medical College and Teaching Hospital, Palpa, Nepal, \\ ${ }^{2}$ Department of Dentistry, Lumbini Medical College and Teaching Hospital, Palpa, Nepal.
}

Introduction: Additional anatomic features present on teeth are called non-metric dental traits. Carabelli's cusp and shovelling are such traits which are mostly evaluated for identification of ethnicity. The present study aims to determine the prevalence of Carabelli's cusp and shovelling among Indo-Nepalese and Tibeto-Nepalese ethnic group.

Methods: A descriptive cross-sectional study was conducted in a tertiary hospital from March 22 to June 222019 after obtaining ethical approval from the institutional review committee. The study was conducted among 274 patients and convenient sampling method was applied. Data were analyzed by the help of Statistical Package for Social Sciences version 21.

Results: Among 274 cases, 153 (55.84\%) cases were Indo-Nepalese and 121 (44.16\%) were TibetoNepalese. Carabelli's cusp (16/26) was noticed in 87 (56.86\%) of Indo-Nepalese and 45 (37.19\%) of Tibeto-Nepalese. Shovelling $(11,12,21,22)$ was present in 47 (30.71\%) Indo-Nepalese and 79 (65.28\%) of Tibeto-Nepalese. Further, Carabelli's cusp (16/26) was found in $77(53.10 \%)$ females and $55(55.12 \%)$ males. Shovelling was present in $75(51.72 \%)$ females and $51(39.53 \%)$ males. Bilateralism with respect to Carabelli's cusp was present in $82(62.2 \%)$ cases. Presence of bilateral shovelling on upper central incisors and lateral central incisors were among 117 (94.35\%) and $56(91.80 \%)$ respectively.

Conclusions: Carabelli's cusps are frequently found in Indo-Nepalese ethnic group and shovelling of teeth most commonly present in Tibeto-Nepalese population. Further, bilaterism for shovelling of teeth is more common than bilaterism for cusp of Carabelli.

Keywords: cusp of carabelli; ethnic groups; identification; incisor.

\section{INTRODUCTION}

Identification of a person based on gender and origin can be successfully carried out by evaluation of additional anatomic features present on the teeth known as non-metric dental traits. Due to their stability and capacity to withstand adverse environment, these traits have been widely applied as a study purpose in forensic anthropology. ${ }^{1-2}$ Cusp of Carabelli and shovelling are two major traits which are frequently observed in human dentition. ${ }^{3}$ cusp of Carabelli, first described in the year 1842 by Carabelli, is an additional lobe of varying degree present on molar teeth, primarily on the first molar. ${ }^{4}$ Shovel incisors are concave and gouged lingual

Correspondence: Dr. Sanjay Kumar Sah, Department of Forensic Medicine \& Toxicology, Lumbini Medical College and Teaching Hospital, Palpa, Nepal. Email: drsanjayshah99@gmail.com, Phone: +977-9842880199. 
surface due to the presence of marginal ridge..$^{5}$ IndoNepalese and Tibeto-Nepalese are two major ethnic groups in residing western hilly region of Nepal. ${ }^{6}$

The present study aims to determine the prevalence of dental morphological traits in both the ethnic groups of western hilly region of Nepal.

\section{METHODS}

The descriptive cross sectional study was carried out in the Department of Dentistry, Lumbini Medical College Teaching Hospital Palpa, Nepal from March 22 to June 22 2019. The study was carried out after obtaining ethical approval from the Institutional Review Committee (IRC-LMC 20A/019). Sample size was calculated by applying formula: $n=Z^{2} \times p \times q / e^{2}$

where,

$\mathrm{n}=$ Sample size

$\mathrm{Z}=1.645$ at Confidence Interval, $90 \%$

$p=$ prevalence in previous similar studies $(63 \%)^{7}$

$e=$ margin of error $=5 \%$

Calculated sample size was 252 and then the study was conducted in 274 patients (145 females and 129 males) of age 14 years and above attending OPD in dental department at Lumbini Medical College Teaching Hospital, Palpa. Convenient sampling method was applied.

Patients with fully erupted permanent first and second molars and all upper permanent incisors were included and the patients having history of cross ethnicity, having restored, carious and missing first and second molars, upper incisors of any side were excluded from the study.

An informed consent was taken prior to examination. Ethnicity was determined based on history of inhabitant, community, homeland and language. The palatal surface of mesio-palatal cusp of left and right first upper molars $(16,26)$ of the subjects were evaluated for cusp of Carabelli. The shovel trait was evaluated in upper incisors $(11,21,12,22)$. Teeth were examined using mouth mirror and dental probe.
Data were analyzed by the help of Statistical Programme for Social Sciences (SPSS) version 21.

\section{RESULTS}

Presence of Carabelli's cusp on either of the upper first molar in Indo-Nepalese ethnic group was 87 (56.86\%) in numbers while in 66 (43.14\%) cases Carabelli's cusp was absent. Among Tibeto-Nepalese ethnic group, Carabelli's cusp was found on 45 (37.19\%) patients and absent in $76(62.81 \%)$ patients. Likewise, the numbers of Indo-Nepalese population in whom shovelling was present on either of upper central and lateral incisors was $47(30.71 \%)$ and in $106(69.29 \%)$ it was absent. Similarly, in Tibeto-Nepalese ethnic group shovelling was present in $79(65.28 \%)$ of cases while in 42 $(34.72 \%)$ cases shovelling was absent. The cusp of Carabelli's was more frequently found on Indo-Nepalese population in comparison to the Tibeto-Nepalese population. Likewise, shovelling was significantly high on Tibeto-Nepalese populations (Table 1).

\begin{tabular}{|c|c|c|c|c|}
\hline \multicolumn{5}{|c|}{$\begin{array}{l}\text { Table 1. Frequency of Carabelli's cusp and shov } \\
\text { in Indo-Nepalese and Tibeto-Nepalese. }\end{array}$} \\
\hline Ethnicity & \multicolumn{2}{|c|}{$\begin{array}{l}\text { Cusp of Carabelli }(16, \\
26)\end{array}$} & \multicolumn{2}{|c|}{$\begin{array}{c}\text { Shovelling } \\
(22,21,12,11)\end{array}$} \\
\hline \multirow[t]{2}{*}{$\begin{array}{l}\text { Indo- } \\
\text { Nepalese }\end{array}$} & $\begin{array}{l}\text { Present } \\
\mathrm{n}(\%)\end{array}$ & $\begin{array}{l}\text { Absent } \\
\mathrm{n}(\%)\end{array}$ & $\begin{array}{l}\text { Present } \\
\mathrm{n}(\%)\end{array}$ & $\begin{array}{l}\text { Absent } \\
\mathrm{n}(\%)\end{array}$ \\
\hline & $\begin{array}{l}87 \\
(56.86)\end{array}$ & $\begin{array}{l}45 \\
(43.14)\end{array}$ & $\begin{array}{l}47 \\
(30.71)\end{array}$ & $\begin{array}{l}106 \\
(69.29)\end{array}$ \\
\hline $\begin{array}{l}\text { Tibeto- } \\
\text { Nepalese }\end{array}$ & $\begin{array}{l}45 \\
(37.19)\end{array}$ & $\begin{array}{l}76 \\
(62.81)\end{array}$ & $\begin{array}{l}79 \\
(65.28)\end{array}$ & $\begin{array}{l}42 \\
(34.72)\end{array}$ \\
\hline
\end{tabular}

Carabelli's cusp on either of upper first molar was found in 77 (53.10\%) females and 55 (55.12\%) males while absent in 68 (46.89\%) females and 74 (44.88\%) males. Shovelling on either of upper central and lateral incisors was observed in $75(51.72 \%)$ females and 51 (39.53\%) males.

Based on ethnicity, Carabelli's cusp was present in 50 (64.93\%) Indo-Nepalese females and 27 (35.06\%) Tibeto-Nepalese females. Likewise, 37 (67.27\%) IndoNepalese males have cusp of Carabelli on either of first molar and 18 (32.77\%) Tibeto-Nepalese have the same. Shovelling was present in $45(60 \%)$ of Tibeto-Nepalese females and 30 (40\%) of Indo-Nepalese females. In case of males, 34 (66.66\%) of Tibeto-Nepalese and 17 (33.34\%) Indo-Nepalese have shovelling on upper incisors (Table 2). 
Sah et al. Prevalence of Selected Non-Metric Dental Traits in Indo-Nepalese and Tibeto-Nepalese Ethnic Groups of Western Hilly Region

\begin{tabular}{|c|c|c|c|c|}
\hline \multirow[b]{2}{*}{ Sex } & \multicolumn{2}{|l|}{ Cusp of Carabelli $(26,16)$} & \multicolumn{2}{|c|}{ Shovelling(22, 21, 12,11) } \\
\hline & Present n (\%) & Absent n (\%) & Present n (\%) & Absent $\mathrm{n}$ ) \\
\hline Female & 77 [IN50 +TN27] (53.10) & $68(46.89)$ & 75 [IN30+TN45] (51.72) & $70(48.28)$ \\
\hline Male & 55 [IN37+TN18] (55.12) & $74(44.88)$ & 51[IN17+TN34] (39.53) & $78(60.47)$ \\
\hline
\end{tabular}

${ }^{*} \mathrm{IN}=$ Indo-Nepalese

*TN=Tibeto-Nepalese

Bilateral presence of Carabelli's cusp was observed in $82(62.12 \%)$ cases while in $50(37.88 \%)$ cases there was unilateral presence of Carabelli's cusp. Likewise, presence of bilateral shovelling on upper central incisor was observed in 117 (94.35\%) and in 7 (5.65\%) cases there was unilaterism of shovelling. For upper lateral incisor, bilaterism was found on 56 (91.80\%) cases and unilaterism was found on 5 (8.2\%) cases (Table 3).

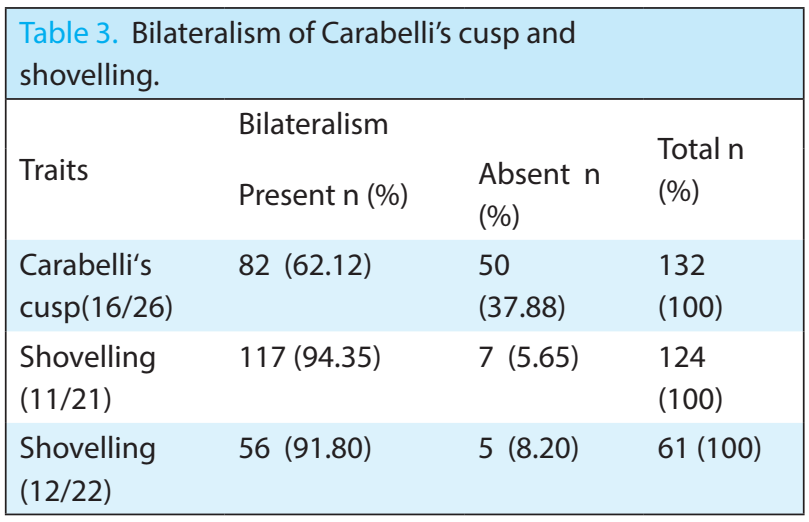

\section{DISCUSSION}

Evaluation of non-metric dental traits can be applied for identification of ethnic group as there is specific prevalence of these traits among particular ethnic group. Nepal is one of the countries having inhabitants of multi-ethnic population. Among them most of the population living in western part of hilly region fall in Indo-Nepalese ethnicity and Tibeto-Nepalese ethnicity. Indo-Nepalese ethnic group comprises of population living at more fertile lower hills, river valleys and Terai plains adjoining boundary of India. The Tibeto-Nepalese ethnic group represents the community occupying the higher hills from west to east. There are numerous studies conducted to differentiate the Mongoloid and Caucasian ethnicity based on presence of cusp of Carabelli and shovel shaped incisors, but only few works have been done previously among the Nepalese population..$^{8-9}$ This study aims to find out prevalence of Carabelli's cusp and shovelling among the population of abovementioned group residing in western hilly region.
In this study, among 274 individuals Carabelli's cusp on upper first molar was observed in $48.2 \%$ and shovelling on upper incisors was found on $46 \%$ individuals. Study done by $\mathrm{M}$ kirtigha et al. on Indian population reported $40.5 \%$ of subjects had cusp of Carabelli on first molar and $68.2 \%$ had shovelling on upper central incisors. ${ }^{10}$ Sadatullah $S$ et al. observed Carabelli's cusp on $41.7 \%$ of Saudi Population. ${ }^{11}$ A study conducted on Nepalese population by Subedi et al. showed presence of Carabelli trait on $68.3 \% .^{7}$

Based on ethnicity, cusp of Carabelli was found on $56.86 \%$ of Indo-Nepalese when compared to the Tibeto-Nepalese where it was present on $37.19 \%$. Similarly, shovelling in upper incisors was found on $65.28 \%$ of Tibeto-Nepalese population and in $30.71 \%$ of Indo-Nepalese population. So, this study reveals high percentage of Carabelli's cusp in Indo-Nepalese population and more prevalence of shovelling on TibetoNepalese population. This study is consistent with the study where presence of shovelling was higher in Mongolids. ${ }^{8}$ Study done by Kharat DU et al. showed shovelling range of $20-25 \%$ in population of Sudan and Egypt. $^{12}$ A study by Srivastava et al. showed only $8 \%$ Tamil population having shovelling. ${ }^{13}$

Overall sex wise distribution of cusp of Carabelli and shovelling shows no significant sexual dimorphism. This finding is similar to study conducted by Talabani $R$ et al. in Iraq. ${ }^{14}$ Subedi et al. presented similar observation on Nepalese population. ${ }^{7}$ But this study showed IndoNepalese ethnic females have higher prevalence of Carabelli's cusp and Tibeto-Nepalese females have higher prevalence of shovelling with comparison to their male counterparts.

In present study bilateral distribution of Carabelli's cusp in upper first molar is $62.12 \%$. Subedi et al. reported $73.7 \%$ in Nepalese population. ${ }^{7}$ A Nigerian study showed bilaterism of $70.71 \%$ with respect to upper first molar. ${ }^{15}$ Shethri SA reported it to be $82.2 \%$ in Saudi population. ${ }^{16}$ Our findings shows $94.35 \%$ bilaterism of shovelling with respect to upper central incisor and $91.80 \%$ with respect to lateral central incisors suggesting shovelling has higher prevalence of shovelling than cusp of Carabelli in Nepalese population. 
In this study only the presence of selected non-metric dental traits namely Carabelli's cusp and shovelling were observed and again those observations were limited to selected teeth. For Carabelli's cusp only upper first molars were evaluated and for shovelling only upper incisors were evaluated based on frequency of their presence. So, further studies among various ethnic groups with respect to various non-metric traits are necessary for validation of use of non-metric dental traits in determining the ethnic identification. Results from our studies can be applied to the population around Palpa district region.

\section{CONCLUSIONS}

Carabelli's cusps are frequently found in Indo-Nepalese ethnic group and shovelling of teeth most commonly present in Tibeto-Nepalese population. Further, bilaterism for shovelling of teeth is more common than bilaterism for cusp of Carabelli.

Conflict of Interest: None.

\section{REFERENCES}

1. Simões RJ, Cardoso HF, Caldas IM. Prevalence of talon cusps in a Portuguese population: Forensic identification significance of a rare trait. Dent Res J (Isfahan). 2014;11(1):45-8. [PubMed | Full Text]

2. Baby TK, Sunil S, Babu SS. Nonmetric traits of permanent posterior teeth in Kerala population: A forensic overview year. J Oral Maxillofac Pathol. 2017;21(2):301-8. [Full Text| DOI]

3. Lee GT, Goose DH. The dentition of Chinese living in Liverpool. Hum Biol. 1972;44:563-72. [PubMed]

4. Mavrodisz K1, Rózsa N, Budai M, Soós A, Pap I, Tarján I. Prevalence of accessory tooth cusps in a contemporary and ancestral Hungarian population. Eur J Orthod. 2007;29(2):166-9. [PubMed $|\underline{\text { Full Text }}| \underline{\text { DOI] }}$

5. G. Richard Scott. Biological Anthropology of the Human Skeleton. $2^{\text {nd }}$ Ed. New Jersey: John Wiley \& Sons. Inc.;2007. 640 p. [Full Text]

6. Caste and Ethnicity [Internet]. Washington DC; US Library of Congress; 1991. Available from: http://countrystudies.us/nepal/31. htm. [Full Text]

7. Subedi N, Sah S, Chataut TP, Paudel S, Pradhan A. The Prevalence of the Carabelli Trait in Selected Nepalese Population. J Adv Med Res. 2015;7(4):285-91. [ [Full Text | DOI]

8. Tsai PL, Hsu JW, Lin LM, Liu KM. Logistic analysis of the effects of shovel trait on Carabelli's trait in a Mongloid population. Am J Phys Anthropol. 1996;100(4):523-30. [PubMed | Full Text | DOI]
9. Hsu JW, Tsai P, Liu K, Ferguson D. Logistic analysis of shovel and Carabelli's tooth traits in a Caucasoid population. Forensic Sci Int. 1997;89(1-2):65-74. [PubMed | Full Text | DOI]

10. Kirthiga M, Manju M, Praveen R, Umesh W. Ethnic association of cusp of Carabelli trait and Shovelling trait in an Indian population. $\mathrm{J}$ Clin Diagn Res. 2016;10(3):ZC78-81. [ [PubMed | Full Text | DOI]

11. Sadatullah S, Odusanya SA, Mustafa A, Razak PA, Wahab MA, Meer Z. The prevalence of fifth cusp (cusp of Carabelli) in the upper molars in Saudi Arabian school students. Int. J. Morphol. 2012;30(2):757-60. [ [Full Text $\mid \underline{\text { DOI] }}$

12. Kharat DU, Saini TS, Mokeem S. Shovel-shaped incisor and associated invagination in some Asian and African populations. J Dent. 1990;18(4):216-20. [PubMed | Full Text]

13. Srivastava M, Bharanidharan R, Ramya R, Dineshkumar T, Kumar AN, Kumar AR. Evaluation of dental non-metric traits in ethnic Tamil population: An aid in forensic profiling. J Clin Diagn Res. 2018;12(10):HC01-HC03. [Full Text | DOI]

14. Talabani RM, Saeed HMM, Hamagharib DS, Khurseed DA. Prevalence of cusp of Carabelli in permanent teeth in a group of dental student of school of dentistry at university of Sulaimani. JDMS. 2015;14(9):115-6. [ Full Text | DOI]

15. Falomo OO. The cusp of Carabelli: frequency, distribution, size and clinical significance in Nigeria. WAJM. 2002;2(4):322-4. [PubMed $\mid \underline{\text { Full Text }]}$

16. Shetri SA. The prevalence of the Carabelli cusp in selected Saudi population. 2011;2:13-6. [Full Text $\mid$ DOI] 